\title{
REVIEW
}

\section{Meniscal pathology - the evidence for treatment}

\author{
Veronica Mezhov ${ }^{\dagger}$, Andrew J Teichtahl $^{\dagger}$, Rupert Strasser, Anita E Wluka and Flavia M Cicuttini ${ }^{*}$
}

\begin{abstract}
Whilst arthroscopic surgery for the treatment of meniscal tears is the most commonly performed orthopaedic surgery, meniscal tears at the knee are frequently identified on magnetic resonance imaging in adults with and without knee pain. The evidence for arthroscopic treatment of meniscal tears is controversial and lacks a supporting evidence base; it may be no more efficacious than conservative therapies. Surgical approaches to the treatment of meniscal pathology can be broadly categorised into those in which partial menisectomy or repair are performed. This review highlights that the major factor determining the choice of operative approach is age: meniscal repair is performed exclusively on younger populations, while older populations are subject to partial menisectomy procedures. This is probably because the meniscus is less amenable to repair in the older population where other degenerative changes co-exist. In middle-aged to older adults, arthroscopic partial menisectomy (APM) may treat the meniscus tear, but does not address the degenerative whole organ disease of knee osteoarthritis. Thus far, there is no convincing evidence that operative approaches are superior to conservative measures as the first-line treatment of older people with knee pain and meniscal tears. However, in two randomised controlled trials (RCTs) approximately one-third of subjects in the exercise groups had persisting knee pain with some evidence of improvement following APM, although the characteristics of this subgroup are unclear. From the available data, a first-line trial of conservative therapy, which includes weight loss, is recommended for the treatment of degenerative meniscal tears in older adults. The exception to this may be when mechanical symptoms, such as knee locking, predominate. Although requiring corroboration by RCTs, there is accumulating evidence from cohort studies and case series that meniscal repair rather than APM may improve function and reduce the long-term risk of knee osteoarthritis in young adults. There is no clear evidence from RCTs that one surgical method of meniscal repair is superior to another.
\end{abstract}

\section{Introduction}

The menisci are fibrocartilaginous structures located between the medial and lateral tibiofemoral joints that function to reduce knee joint loads by shock absorption. When severe, meniscal tears are implicated in knee locking and pain. However, using magnetic resonance imaging, meniscal tears are present in approximately $20 \%$ of people without knee symptoms [1]. Indeed, meniscal pathology is now considered part of the spectrum of pathology seen in knee osteoarthritis (OA) and meniscal tears are a risk factor for further deleterious structural change, such as accelerated articular cartilage loss [2].

In 1942, McMurray commented that 'a far too common error is shown in the incomplete removal of the

\footnotetext{
* Correspondence: flavia.cicuttini@monash.edu

${ }^{\dagger}$ Equal contributors

Department of Epidemiology and Preventive Medicine, School of Public Health and Preventive Medicine, Monash University, Alfred Hospital, Melbourne, VIC 3004, Australia
}

injured meniscus' [3]. However, total menisectomy has since then been shown detrimental to the knee joint. In 1948, after total menisectomy, anteroposterior ridging occurred at the femoral condyle, with flattening of the articular surface and joint space narrowing [4]. Contemporary studies have substantiated these findings, with radiographic OA being 14 times more common in people two decades after having had a total menisectomy compared with age-matched and gender-matched controls [5]. Recently, a prospective longitudinal 40-year follow-up study examined people who underwent open total menisectomy as adolescents for isolated meniscal pathology. The results showed that total menisectomy increased the risk of symptomatic knee OA in later life, with a resultant 132-fold increase in the rate of knee replacement compared with geographical and age-matched controls [6].

The advent of arthroscopic surgery has enabled the resection of minimum amounts of damaged meniscal tissue, and even meniscal repair. In vitro studies have demonstrated that joint stresses are related to the amount of 
meniscus removed [7]. When patients undergoing partial or total menisectomy have been compared, the amount of tissue resected was demonstrated to be inversely related to knee function [8]. Arthroscopic partial menisectomy (APM) remains the most common surgical intervention for meniscal pathology and the most common orthopaedic surgical procedure in the United States, with more than 465,000 people undergoing the procedure annually [9]. Nevertheless, there is a paucity of data examining the efficacy of treatments available for meniscal tears. For instance, there is no study that has compared whether APM is superior to nonoperative therapy in the treatment of traumatic meniscal tears. There are, however, some commonalities emerging from both randomised controlled trials (RCTs) and observational studies that have examined therapeutic interventions for meniscal pathology.

This review aims to examine the evidence underlying the use of arthroscopic interventions and conservative measures such as physical therapy, weight loss and analgesia in the management of meniscal tears.

\section{Evidence for arthoscopic partial menisectomy}

Several studies have examined the evidence for APM, either as cohort studies or RCTs (Table 1). Other than one study [10], all data examining APM have examined subjects with a mean age of 43 years or older. These studies have failed to demonstrate superiority of APM over conservative measures.

\section{Nonrandomised studies}

Three nonrandomised studies have examined the efficacy of menisectomy [11-13]. As opposed to RCTs, which have primarily focused on pain as the primary outcome, cohort studies have focused on the development of incident radiographic knee OA as the outcome of interest. A study examined the risk of developing knee OA following either partial, subtotal or total menisectomy and compared the risk against people who had a meniscal tear but did not undergo menisectomy 15 to 22 years prior [11]. This study found that partial menisectomy was associated with less radiographic OA than was total menisectomy. Nevertheless, symptomatic radiographic knee OA was more likely to occur in operated knees (27\%) than in control knees $(10 \%)$ (relative risk $=2.6 ; 95 \%$ confidence interval $=1.3$ to 6.1), regardless of the type of resection performed [11].

In a retrospective study that compared outcomes of people with intact anterior cruciate ligaments (ACLs) who had undergone APM for an isolated meniscal tear, it was found that there was a high risk of radiographic and symptomatic OA at 16-year follow-up [12]. In subgroup analyses, outcomes were worse in those with degenerative tears and extensive resection. Such findings prompted the authors to conclude that degenerative meniscal tears may be associated with incipient
$\mathrm{OA}$, and that the meniscal tear may herald the onset of disease.

The final cohort study examined older people with symptomatic meniscal tears, although the symptoms were ill-defined [13]. Participants underwent debridement of unstable articular cartilage and were subject to either arthroscopic washout or APM. At 12 months, there was greater improvement in symptoms after APM than washout alone, with lower analgesic requirements. However, these results should be taken in the context that most participants underwent APM $(n=126)$, with only 13 subjects having had a washout. Such a disparity in numbers between the groups challenges the results of the study and the conclusion that APM assists in symptom control.

\section{Randomised controlled trials}

Data from RCTs have yielded conflicting results regarding the efficacy of APM versus conservative therapies (Table 1). As opposed to cohort studies, which have primarily focused on incident radiographic knee OA as the primary outcome, RCTs have predominantly focused on pain as the outcome of interest.

Four RCTs have compared APM with physical therapy in older (mean age $\geq 45$ years) individuals with symptomatic knee OA [14-17], while one RCT compared APM with sham surgery in people with medial mensical tears [18]. The primary outcomes in these studies were clinical measures of pain and function, using validated instruments, including the Western Ontario and McMaster Universities Arthritic Index, the Knee Injury and Osteroarthritis Outcome Score, the Lysholm Knee Score, the Tegner activity level and visual analogue scales. In all RCTs, both the APM and physical therapy groups showed clinical improvements from baseline to follow-up, although superiority of APM compared with physical therapy could not be demonstrated at any time point. In the most recent RCT [16], no significant differences in terms of relief of knee pain, improved knee function or patient satisfaction between APM and strengthening exercises could be discerned over 2 years of follow-up. In the study by Herrlin and colleagues, one-third of the patients in the exercise group had persisting and disabling knee symptoms after exercise therapy, but improved to the same degree as the APM group when APM was then employed among people who had initially failed to respond to exercise [17]. Nevertheless, the group who required eventual APM were ill-defined. Possibly their symptoms were of a major mechanical origin, whereby knee locking predominated, and such a select subgroup may therefore benefit from APM as first-line treatment. One must acknowledge, however, that two-thirds of subjects responded to exercise therapy, avoiding APM. Caution should therefore be exercised when advocating APM over conservative therapies 


\begin{tabular}{|c|c|c|c|c|c|c|}
\hline Study & Study description & Group 1 & Group 2 & $\begin{array}{l}\text { Outcome } \\
\text { measure }\end{array}$ & Results & Conclusion \\
\hline \multicolumn{7}{|c|}{ Randomised control trials } \\
\hline $\begin{array}{l}\text { Sihoven and } \\
\text { colleagues, } 2013 \text { [18] }\end{array}$ & $\begin{array}{l}\text { Multicentre with symptomatic } \\
\text { medial meniscal tear }\end{array}$ & APM & Sham surgery & Symptoms & $\begin{array}{l}\text { No significant between-group } \\
\text { differences from baseline to } \\
12 \text { months in any primary } \\
\text { outcome (LKS, WOMET and } \\
\text { knee pain after exercise) }\end{array}$ & $\begin{array}{l}\text { APM not superior to sham } \\
\text { surgery in reducing knee } \\
\text { symptoms at } 12 \text { months }\end{array}$ \\
\hline $\begin{array}{l}\text { Yim and colleagues, } \\
2013 \text { [16] }\end{array}$ & $\begin{array}{l}\text { Degenerative horizontal tear of } \\
\text { posterior horn of medial meniscus } \\
\text { on MRl; mean age } 53.8 \text { years } \\
\text { (range } 43 \text { to } 62 \text { years); follow-up } \\
2 \text { years }\end{array}$ & APM, $n=50$ & $\begin{array}{l}\text { Strengthening } \\
\text { exercises, } n=52\end{array}$ & Symptoms & $\begin{array}{l}\text { Both groups reported an } \\
\text { improvement in knee pain, } \\
\text { function and a high level of } \\
\text { treatment satisfaction using } \\
\text { VAS, LKS, Tegner activity scale, } \\
\text { patient subjective knee pain } \\
\text { and satisfaction. No significant } \\
\text { between-group differences }\end{array}$ & $\begin{array}{l}\text { APM not superior to } \\
\text { strengthening exercises } \\
\text { in terms of improved knee } \\
\text { pain, function or treatment } \\
\text { satisfaction }\end{array}$ \\
\hline $\begin{array}{l}\text { Katz and colleagues, } \\
2013 \text { [15] }\end{array}$ & $\begin{array}{l}\text { Symptomatic meniscal tear; } \\
\text { age } \geq 45 \text { years; } 6 \text {-month and } \\
12 \text {-month follow-up }\end{array}$ & $\begin{array}{l}\text { APM and postoperative } \\
\text { PT, } n=161 ; \text { mean age } \\
59.9 \pm 7.9\end{array}$ & $\begin{array}{l}\text { PT alone, } n=169 ; \\
\text { mean age } 57.8 \pm 6.8\end{array}$ & Symptoms & $\begin{array}{l}\text { WOMAC at } 6 \text { and } 12 \text { months } \\
\text { improvement in both groups } \\
\text { but no between-group differences; } \\
30 \% \text { crossover from PT alone } \\
\text { within first } 6 \text { months }\end{array}$ & $\begin{array}{l}\text { APM + PT not superior to } \\
\text { PT for pain reduction }\end{array}$ \\
\hline $\begin{array}{l}\text { Herrlin and colleagues, } \\
2013[17]\end{array}$ & $\begin{array}{l}\text { Symptomatic medial meniscal tear } \\
\text { and radiographic OA; } 24-\text { month } \\
\text { and } 60 \text {-month follow-up }\end{array}$ & $\begin{array}{l}\text { APM followed by } \\
\text { exercise therapy for } \\
2 \text { months, } n=47 \text {; } \\
\text { median age } 54 \text { years }\end{array}$ & $\begin{array}{l}\text { Exercise alone, } n=49 \\
\text { median age } 56 \text { years }\end{array}$ & Symptoms & $\begin{array}{l}\text { Clinical improvement in both } \\
\text { groups on all subscales of KOOS, } \\
\text { LKS and VAS }(P<0.0001) \text {. One- } \\
\text { third of exercise-alone patients that } \\
\text { failed to respond had a benefit } \\
\text { from then having APM }\end{array}$ & $\begin{array}{l}\text { APM + exercise not } \\
\text { superior to exercise alone }\end{array}$ \\
\hline $\begin{array}{l}\text { Herrlin and colleagues, } \\
2007[14]\end{array}$ & $\begin{array}{l}\text { Knee pain and underlying OA with } \\
\text { medial meniscal tear; mean age } \\
56 \text { years; 8-week and 6-month } \\
\text { follow-up }\end{array}$ & $\begin{array}{l}\text { APM and supervised } \\
\text { exercise, } n=47\end{array}$ & $\begin{array}{l}\text { Supervised exercise } \\
\text { alone, } n=43\end{array}$ & Symptoms & $\begin{array}{l}\text { Both groups reported decreased } \\
\text { knee pain, improved function and } \\
\text { high satisfaction. No between-group } \\
\text { differences }\end{array}$ & $\begin{array}{l}\text { APM + exercise not superior } \\
\text { to exercise alone }\end{array}$ \\
\hline Beidert, 2000 [10] & $\begin{array}{l}\text { Painful intrasubstance medial } \\
\text { meniscal tear; mean age } 30.4 \text { years } \\
\text { (range } 16 \text { to } 50 \text { years); } 26.5 \text {-month } \\
\text { follow-up }\end{array}$ & Group D: APM, $n=11$ & $\begin{array}{l}\text { Group A: PT and } \\
\text { NSAIDs, } n=12\end{array}$ & Symptoms & $\begin{array}{l}\text { Normal/near-normal IKDC. } \\
\text { Group A. } 75 \% \text {; Group D. } 100 \% \text {, } \\
P=0.006\end{array}$ & $\begin{array}{l}\text { APM superior to } \\
\text { conservative therapy }\end{array}$ \\
\hline
\end{tabular}

APM and postoperative PT alone $n=169$; Symptoms WOMAC at 6 and 12 months PT $n=161 \cdot$ mean age mean age $57.8+6.8$ $59.9 \pm 7.9$ 2 months, $n=47$; 2 months, $n=47 ;$

APM and supervised - niscal tear; mean age follow-up 
Table 1 Evidence for arthroscopic partial meniscectomy (Continued)

Cohort studies

\section{Englund and}

Retrospective case-control study;

prior: mean age 54 years at

follow-up ( \pm 11 years)

Englund and

Retrospective analyses of patients APM or subtotal

colleagues, 2003 [12] earlier; mean age 54 years at

follow-up ( \pm 12 years)
Control group with no Structure

meniscal tear, previous

surgery or cruciate

pathology, $n=68$

Age, gender and BMI Structure

matched controls,

$n=68$; mean age:

56.3 years
Radiographic (RR 5.4, 95\% Cl 2.5 to 13) Menisectomy associated and symptomatic (RR 2.6, 95\% C

1.3 to 6.1 ) knee OA more common in operated knees than in controls. Total meniscectomy rather than APM had higher likelihood of knee OA (OR 3.6, $95 \%$ Cl 1.4 to 9.4$)$

Increased RR of knee OA (RR 4.8, $95 \% \mathrm{Cl} 2.2$ to 12 ) and symptom development (RR 2.6, 95\% Cl 1.6 to 4.7 ) of knee OA in meniscectomy group. Subtotal menisectomy associated with significantly worse joint space

narrowing and KOOS scores than APM with higher risk of developing

knee OA. APM associated with

位s radiographic knee OA than

total menisectomy

APM or subtotal associated with high risk of radiographic and

symptomatic OA at 16-year

follow-up. Outcomes worse in degenerative tears and extensive resection

APM, arthroscopic partial menisectomy; BMI, body mass index; Cl, confidence interval; MRI, magnetic resonance imaging; NSAID, nonsteroidal anti-inflammatory drug; OA, osteoarthritis; PT, physical therapy; RR, relative risk. Western Ontario Meniscal Evaluation Tool (WOMET) is a disease-specific quality-of-life measurement tool for patients with meniscal lesions looking at symptoms (pain, giving way, swelling, stiffness, numbness, loss of motion), sports/recreation/lifestyle/work and emotion. Western Ontario and McMaster Universities Arthritis Index (WOMAC) evaluates the condition of patients with osteoarthritis of the knee and hip, including pain, stiffness, and physical functioning of the joints. Knee Injury and Osteoarthritis Outcome Score (KOOS) evaluates short-term and long-term patient-related outcomes following injury including pain, other symptoms such as catching/locking/swelling, activities of daily living, sport and recreation function, and knee-related quality of life. Lysholm knee scoring (LKS) scale for knee ligament injuries including pain, swelling, locking, limping, stair climbing, support and squatting. Visual analogue scale (VAS) is a subjective measurement of pain consisting of a line $10 \mathrm{~cm}$ long where on one end is 'no pain' and on the other is the 'worst pain imaginable'. International Knee Documentation Committee score (IKDC) is a score to evaluate knee ligament injuries including three domains of symptoms (pain, locking, catching, swelling, stiffness), sports and daily activities and current knee function (compared with old knee function). 
from this study. No between-group differences existed for improvement in pain levels 12 months postprocedure for both the APM and sham surgery groups in people with medial meniscal tears [18].

Another small RCT examined people with a mean age of 30.4 years (range 16 to 50 years) with a symptomatic medial meniscal tear and randomised them to several treatment arms, which included conservative treatment (nonsteroidal anti-inflammatory drugs and local physical therapy, $n=12)$ and APM $(n=11)$ [10]. At just over 2year follow-up, people who had an APM demonstrated better outcomes than conservative therapies. Indeed all subjects had a near-normal International Knee Documentation Committee (IKDC) score with APM, compared with $75 \%$ with conservative measures $(P=0.006)$. The IKDC is a composite score that evaluates ligament injuries examining four major domains of symptoms (pain, locking, swelling, stiffness). Such results may therefore support the use of APM among younger people with meniscal tears. However, this study was limited by the small number of subjects completing the RCT $(n=23)$, and these results need to be corroborated in a larger RCT. It is also unclear whether the $25 \%$ of subjects who did not normalise their IKDC score had specific symptoms, such as knee locking, and therefore represented a select subgroup of people who were unlikely to improve with conservative measures. It must be acknowledged that $75 \%$ of patients still improved to be normal or near-normal with regards to their IKDC scores in the nonoperative group, therefore avoiding APM.

\section{Meniscal repair}

Whilst APM is one of the most commonly performed orthopaedic procedures [19], meniscal repair is the treatment of choice for the young athlete with an acute meniscal tear [20]. Meniscal repair is most commonly performed in younger populations aged under 35 years [10,21-27] and aims to preserve the entire meniscus, without excision. The rationale for meniscal repair is that by preserving the structure of the meniscus, function is maintained and long-term changes in other joint structures will be ameliorated.

The indications for performing a meniscal repair include: location (peripheral tears are located in a more vascular area and therefore heal better), morphology (shorter $2 \mathrm{~cm}$ tears and vertical longitudinal tears are more amenable to repair versus longer and degenerative horizontal tears) and chronicity (acute tears more amenable to repair). These conditions are rarely met in older patients, where degenerative meniscal tears are more apparent. Meniscal repair is thus performed exclusively in younger patients. Older patients are more likely to have degenerative tears that are not amenable to repair $[28,29]$.
Currently, there are three arthroscopic techniques for meniscal repair in common use: the outside-in suture, the inside-out technique [30,31], and the all-inside technique that uses biodegradable products [32]. The outside-in technique uses spinal needles and sutures passed from outside to inside of the joint under arthroscopic observation. Tears in the anterior or body of the medial or lateral meniscus are easily accessed with the outside-in technique. For far posterior tears, which are harder to access, the inside-out or all-inside techniques are preferred [30].

\section{Evidence for meniscal repair}

RCTs examining meniscal repairs have primarily focused on the differences in surgical methods, including failure and healing rates, as well as re-tear rates. In contrast, cohort studies have examined pain, function and radiographic knee OA as outcomes.

\section{Nonrandomised studies}

Two cohort studies have compared meniscal repair to APM [25,27]. Melton and colleagues compared people requiring ACL reconstruction with the additional intervention of either inside-out suture repair $(n=35)$ or APM $(n=27)$ [27]. A control group requiring ACL reconstruction with intact menisci was also included $(n=40)$. The mean age of the patients in all treatment arms was less than 30 years. This study demonstrated that over a median follow-up of 10 years, the IKDC score for patients with meniscal repair was better than for those who underwent APM [27]. In another cohort study examining young adults, although it was shown that individuals who had APM returned to professional and sporting activities earlier than people with meniscal tear, there was less knee OA in the meniscal repair group at 7 year follow-up [25]. Similarly, a slightly larger cohort study of young athletes demonstrated that OA was less common in people who had previously had meniscal repair compared with those people who underwent APM [26]. In a follow-up case series of people who had longitudinal meniscal repairs with concurrent ACL repair when aged 20 years or younger, there appeared to be a chondroprotective effect from surgery, with a low rate of radiographic knee OA at a minimum of 10 years postoperatively [33]. Although there was a lack of a control group, the limited data may support the use of meniscal repair in select cases.

\section{Randomised controlled trials}

Although five RCTs have examined the efficacy of meniscal repair (see Table 2), four of these studies have compared different surgical interventions, rather than comparing meniscal repair with other treatments, such as physical therapy. Nevertheless, regardless of the operative approach, symptom improvement occurred in most instances of meniscal repair, although superiority 


\section{Table 2 Evidence for meniscal repair}

\begin{tabular}{|c|c|c|c|c|c|c|c|c|}
\hline Study & $\begin{array}{l}\text { Study } \\
\text { description }\end{array}$ & Group 1 & Group 2 & Group 3 & Group 4 & $\begin{array}{l}\text { Outcome } \\
\text { measure }\end{array}$ & Results & Conclusion \\
\hline \multicolumn{9}{|c|}{ Randomised control trials } \\
\hline $\begin{array}{l}\text { Jarvela and } \\
\text { colleagues, } 2010 \text { [21] }\end{array}$ & $\begin{array}{l}\text { Degenerative meniscal } \\
\text { tear or knee OA } \\
\text { excluded; 2-year } \\
\text { follow-up }\end{array}$ & $\begin{array}{l}\text { Screws, } n=21 \\
\text { mean age } \\
30 \text { years } \\
( \pm 9 \text { years) }\end{array}$ & $\begin{array}{l}\text { Arrows, } n=21 ; \\
\text { mean age } \\
32 \text { years ( } \pm 9 \text { years) }\end{array}$ & N/A & N/A & $\begin{array}{l}\text { Surgical failure. } \\
\text { Structure }\end{array}$ & $\begin{array}{l}\text { No between-group } \\
\text { differences for surgical } \\
\text { failure rate }(P=0.242) \text {. } \\
\text { More chondral damage } \\
\text { with arrows }(P=0.018)\end{array}$ & $\begin{array}{l}\text { Similar surgical outcomes. } \\
\text { Arrows caused more } \\
\text { chondral damage }\end{array}$ \\
\hline $\begin{array}{l}\text { Bryant and } \\
\text { colleagues, } 2007 \text { [22] }\end{array}$ & $\begin{array}{l}\text { Vertical meniscal } \\
\text { tears only; 28-month } \\
\text { follow-up }\end{array}$ & $\begin{array}{l}\text { Sutures, } n=49 ; \\
\text { mean age } \\
25.7 \text { years } \\
( \pm 9 \text { years })\end{array}$ & $\begin{array}{l}\text { Arrows, } n=51 \\
\text { mean age } \\
25.1 \text { years } \\
\text { ( } \pm 8 \text { years })\end{array}$ & N/A & N/A & $\begin{array}{l}\text { Re-tear rate. } \\
\text { Symptoms and } \\
\text { quality of life }\end{array}$ & $\begin{array}{l}\text { No significant } \\
\text { between-group } \\
\text { differences for re-tear } \\
\text { rate. No significant } \\
\text { between-group } \\
\text { differences for QOL } \\
\text { or WOMET scores }\end{array}$ & $\begin{array}{l}\text { No difference between } \\
\text { the two different repair } \\
\text { methods }\end{array}$ \\
\hline $\begin{array}{l}\text { Hantes and } \\
\text { colleagues, } 2006 \text { [23] }\end{array}$ & $\begin{array}{l}\text { Those with knee } \\
\text { OA at arthroscopy } \\
\text { excluded; 23-month } \\
\text { follow-up }\end{array}$ & $\begin{array}{l}\text { Group A: } \\
\text { Outside-in, } n=17 \\
\text { (14 medial meniscus); } \\
\text { mean age } 28.5 \text { years }\end{array}$ & $\begin{array}{l}\text { Group B: } \\
\text { Inside-out, } \\
n=20 \text { ( } 17 \text { medial } \\
\text { meniscus); mean } \\
\text { age } 28 \text { years }\end{array}$ & $\begin{array}{l}\text { Group C: } \\
\text { All-inside, } \\
n=20 \text { ( } 17 \text { medial } \\
\text { meniscus); mean } \\
\text { age } 25 \text { years }\end{array}$ & N/A & $\begin{array}{l}\text { Operative time } \\
\text { and healing } \\
\text { rate }\end{array}$ & $\begin{array}{l}\text { Healing rate in group C } \\
\text { inferior to groups A and } \\
\text { B. Group B was quickest } \\
\text { procedure }\end{array}$ & $\begin{array}{l}\text { Inside-out technique } \\
\text { superior to other two } \\
\text { as high rate of healing } \\
\text { without prolonged } \\
\text { operation time }\end{array}$ \\
\hline Beidert, 2000 [10] & $\begin{array}{l}\text { Painful intrasubstance } \\
\text { medial meniscal tear; } \\
\text { mean age } 30.4 \text { years } \\
\text { (range } 16 \text { to } 50 \text { years); } \\
\text { 26.5-month follow-up }\end{array}$ & $\begin{array}{l}\text { Suture repair, } \\
n=10\end{array}$ & $\begin{array}{l}\text { PT and NSAIDs, } \\
n=12\end{array}$ & $\begin{array}{l}\text { Minimal } \\
\text { resection, fibrin } \\
\text { clot, suture } \\
\text { repair, } n=7\end{array}$ & $\begin{array}{l}\text { APM, } \\
n=11\end{array}$ & Symptoms & $\begin{array}{l}\text { Normal/near normal } \\
\text { IKDC. Group 1,75\%; } \\
\text { Group 2, 90\%; Group 3, } \\
\text { 43\%; Group 4, 100\% }\end{array}$ & $\begin{array}{l}\text { Intra-substance } \\
\text { (degenerative) meniscal } \\
\text { tears were shown to be } \\
\text { best treated by APM. } \\
\text { Meniscal repair might give } \\
\text { better medium-term to } \\
\text { long-term results }\end{array}$ \\
\hline $\begin{array}{l}\text { Albrecht-Olsen and } \\
\text { colleagues, } 1999 \text { [24] }\end{array}$ & $\begin{array}{l}\text { Those with OA at } \\
\text { arthroscopy excluded; } \\
\text { 3-month to 4-month } \\
\text { follow-up }\end{array}$ & $\begin{array}{l}\text { Inside-out sutures, } \\
n=32 \text { ( } 21 \text { medial); } \\
\text { median age } \\
25.5 \text { years (range } \\
18 \text { to } 40 \text { years) }\end{array}$ & $\begin{array}{l}\text { All-inside meniscal } \\
\text { arrows, } n=33 \\
\text { ( } 21 \text { medial); median } \\
\text { age } 26.5 \text { years } \\
\text { (range } 18 \text { to } 37 \text { years) }\end{array}$ & N/A & N/A & Healing rates & $\begin{array}{l}\text { No between-group } \\
\text { differences for healing } \\
(P=0.11) \text {. No between- } \\
\text { group differences in } \\
\text { subgroup analyses, } \\
\text { dependent on } A C L \\
\text { reconstructed or ACL } \\
\text { insufficient knees }\end{array}$ & $\begin{array}{l}\text { Similar outcome with two } \\
\text { meniscal repair procedures }\end{array}$ \\
\hline \multicolumn{9}{|l|}{ Cohort studies } \\
\hline $\begin{array}{l}\text { Melton and } \\
\text { colleagues, } 2011 \text { [27] }\end{array}$ & $\begin{array}{l}\text { ACL lesions without } \\
\text { degenerative changes; } \\
\text { median 10-year } \\
\text { follow-up; mean age } \\
28 \text { years (range } 20 \\
\text { to } 53 \text { years) }\end{array}$ & $\begin{array}{l}\text { Inside-out repair, } \\
n=35 \text { ( } 32 \text { medial); } \\
\text { mean age } 28 \text { years }\end{array}$ & $\begin{array}{l}\text { APM, } n=40 ; \\
\text { mean age } 27 \text { years }\end{array}$ & $\begin{array}{l}\text { Intact menisci, } \\
n=40 ; \text { mean } \\
\text { age } 27\end{array}$ & N/A & Symptoms & $\begin{array}{l}\text { Mean IKDC significantly } \\
\text { higher in meniscal repair } \\
\text { group compared with } \\
\text { menisectomy group }\end{array}$ & $\begin{array}{l}\text { Improved functional scores } \\
\text { achieved in people with } \\
A C L \text { reconstruction and } \\
\text { meniscal repair compared } \\
\text { with } A C L \text { reconstruction } \\
\text { and menisectomy }\end{array}$ \\
\hline
\end{tabular}


Table 2 Evidence for meniscal repair (Continued)

\begin{tabular}{|c|c|c|c|c|c|c|c|c|}
\hline $\begin{array}{l}\text { Stein and } \\
\text { colleagues, } 2010 \text { [26] }\end{array}$ & $\begin{array}{l}\text { Traumatic meniscal } \\
\text { tear; mid-term } \\
\text { follow-up at } 3.4 \text { years } \\
(n=35) \text {; long-term } \\
\text { follow-up at } 8.8 \text { years } \\
(n=46)\end{array}$ & $\begin{array}{l}\text { Meniscal repair, } \\
n=42 ; \text { mean } \\
\text { age } 31.2\end{array}$ & $\begin{array}{l}\text { APM, } n=39 ; \\
\text { mean age } 30.4\end{array}$ & N/A & $\mathrm{N} / \mathrm{A}$ & $\begin{array}{l}\text { Structure and } \\
\text { function }\end{array}$ & $\begin{array}{l}\text { Significantly less } \\
\text { progression of OAO } \\
(P=0.005) \text {; greater } \\
\text { preinjury activity level } \\
(P=0.001) \text { and greater } \\
\text { sporting activity among } \\
\text { athletes }(P=0.001) \text { in } \\
\text { people treated with } \\
\text { meniscal repair }\end{array}$ & $\begin{array}{l}\text { Meniscal repair associated } \\
\text { with better outcomes } \\
\text { than APM }\end{array}$ \\
\hline $\begin{array}{l}\text { Sommerlath, } \\
1991 \text { [25] }\end{array}$ & $\begin{array}{l}\text { Baseline symptoms } \\
\text { not reported; knee } \\
\text { OA excluded; } \\
\text { 7-year follow-up }\end{array}$ & $\begin{array}{l}\text { Open suture } \\
\text { meniscal repair, } \\
n=34 ; \text { mean age } \\
27 \text { years }\end{array}$ & $\begin{array}{l}\text { APM, } n=26 \\
\text { mean age } 27 \text { years }\end{array}$ & N/A & $\mathrm{N} / \mathrm{A}$ & $\begin{array}{l}\text { Symptoms. } \\
\text { Structure }\end{array}$ & $\begin{array}{l}\text { In meniscal repair group, } \\
\text { significantly: higher LKS } \\
\text { scores; less OA; longer } \\
\text { return to professional } \\
\text { activities }\end{array}$ & $\begin{array}{l}\text { Reduced OA in meniscal } \\
\text { repair group despite longer } \\
\text { return to work than people } \\
\text { receiving APM }\end{array}$ \\
\hline
\end{tabular}

$\overline{\mathrm{ACL}}$, anterior cruciate ligament; APM, arthroscopic partial menisectomy; N/A, not available; NSAID, nonsteroidal anti-inflammatory drug; OA, osteoarthritis; PT, physical therapy. Western Ontario Meniscal Evaluation Tool (WOMET) is a disease-specific quality-of-life measurement tool for patients with meniscal lesions looking at symptoms (pain, giving way, swelling, stiffness, numbness, loss of motion), sports/recreation/lifestyle/work and emotion. Quality-of-life (QOL) outcome measure consists of 32 items that address each of five separate quality-of-life domains: symptoms and physical complaints, work-related concerns, recreational activities and sports participation, life-style, and social and emotional concerns. Lysholm knee scoring (LKS) scale for knee ligament injuries including pain, swelling, locking, limping, stair climbing, support and squatting. current knee function (compared with old knee function). 
of one meniscal repair technique over another was generally not demonstrable.

To our knowledge, only one small study examining young adults has compared surgical interventions with conservative management (nonsteroidal anti-inflammatory drugs and physical therapy) [10]. This study compared four different treatment arms and found the following improvement at 26.5-month follow-up, as determined by clinical examination, IKDC score, radiographs and magnetic resonance imaging: conservative therapy (75\%), arthroscopic suture repair with access channels (90\%), arthroscopic minimal central resection, intrameniscal fibrin clot and suture repair (43\%), and APM (100\%). Such results demonstrated that APM and suture repair are superior treatments compared with conservative therapy in young adults over the short term, although in this small study there was no statistical difference between APM and meniscal repair groups.

\section{Conservative therapies}

\section{Physical therapy}

As discussed earlier, several RCTs have compared the effect of physical therapy or APM in people with a meniscal tear (see Table 3) [14-17]. No RCT examining older adults has demonstrated a significant difference in the symptoms experienced after completion of a physical therapy programme compared with APM. A smaller RCT, however, did show greater symptom improvement in younger people after APM than physical therapy, although $75 \%$ of people with physical therapy still had significant improvement in their knee pain [10].

\section{Weight loss}

A recent cohort study examined the effects of weight change on knee pain in participants with and without meniscal tears (Table 3) [34]. Two hundred and fifty participants (mean age 46.7 years) with no history of knee OA were recruited from the community, and the outcome measures were change in cartilage volume and Western Ontario and McMaster Universities Arthritic Index knee pain measured over approximately 2.4 years. Methods for weight loss included either surgical (laparoscopic adjustable gastric banding) or caloric restriction. Results showed that small increases in weight expedited cartilage volume loss and increased knee pain among people with medial meniscal tears only. Conversely, as little as $1 \%$ loss of weight was associated with a reduction in the rate of cartilage volume loss and an improvement in knee pain in people with, but not without, medial meniscal tears. This study suggested that in adults with medial meniscal tears, attention to weight is an important factor in the conservative management of meniscal tears.

\section{Meniscal tears - the treatment conundrum}

Although there is a paucity of evidence examining the efficacy of treatments available for meniscal tears, there are some commonalities emerging from both RCTs and observational studies.

Overwhelming evidence has demonstrated the poor long-term outcomes from total menisectomy, and this procedure should be considered a procedure of yesteryear [4-6]. All APM, meniscal repair and physical therapy have been shown to be associated with symptom improvement, although there are conflicting data regarding the comparative superiority of the surgical versus the conservative approach. While one RCT demonstrated that APM was superior to conservative measures, the between-group comparison was limited by a small number of subjects $(n=23)$ who were young (mean age 30.4 years) [10]. The other four larger RCTs have examined older subjects and have failed to demonstrate superiority of APM over conservative measures [14-17]. This discrepancy between studies may be attributable to the different ages of the cohort.

With the passage of time, OA changes within the joint accumulate and age may be a surrogate for cumulative joint damage. In this instance, an operative approach in older persons may not yield as much symptomatic benefit, because other abnormalities in joint structures may contribute to the knee pain and reduced function which prompted medical attention to be initially sought. In people with radiographic knee OA, $63 \%$ of people with knee pain have co-existing meniscal tears while $60 \%$ of people without knee pain also had a meniscal tear [1]. This begs the question of whether the degenerative meniscal tear is a contributor to the joint symptoms or is simply a marker of the OA process. Age also appears to be a major determinant of the surgical approach as meniscal repair has been performed exclusively in younger populations whereby OA changes have been an exclusion criterion. This is presumably because whereas middle-aged and older adult meniscal tears are degenerative, younger patients have menisci that are more amenable to repair. Nevertheless, there may be rare circumstances where meniscal repair may be indicated in the older adult, provided there is good quality tissue, an acute tear and appropriate vascularity.

In the small RCT performed in young adults that demonstrated the superiority of APM over conservative measures, $75 \%$ of subjects undergoing treatment with nonsteroidal anti-inflammatory drugs and physical therapy still had improvement to normal or near-normal IKDC scores. The added economical and surgical risks associated with APM may not justify this approach as first-line therapy. Indeed, an emerging theme in most of the RCTs is that approximately one-third of subjects did not have an adequate response to conservative measures. 


\begin{tabular}{|c|c|c|c|c|c|c|c|c|}
\hline Study & Study description & Group 1 & Group 2 & Group 3 & Group 4 & $\begin{array}{l}\text { Outcome } \\
\text { measure }\end{array}$ & Results & Conclusion \\
\hline \multicolumn{9}{|l|}{ Physical therapy } \\
\hline $\begin{array}{l}\text { Yim and colleagues, } \\
2013 \text { [16] }\end{array}$ & $\begin{array}{l}\text { Degenerative horizontal } \\
\text { tear of posterior horn of } \\
\text { medial meniscus on MRI; } \\
\text { mean age } 53.8 \text { years } \\
\text { (range } 43 \text { to } 62 \text { years); } \\
\text { 2-year follow-up }\end{array}$ & APM, $n=50$ & $\begin{array}{l}\text { Strengthening } \\
\text { exercises, } n=52\end{array}$ & N/A & N/A & Symptoms & $\begin{array}{l}\text { Both groups reported an } \\
\text { improvement in knee pain, } \\
\text { function and a high level of } \\
\text { treatment satisfaction using } \\
\text { VAS, LKS, Tegner activity scale, } \\
\text { patient subjective knee pain } \\
\text { and satisfaction. No significant } \\
\text { between-group differences }\end{array}$ & $\begin{array}{l}\text { APM not superior to } \\
\text { strengthening exercises } \\
\text { in terms of improved } \\
\text { knee pain, function or } \\
\text { treatment satisfaction }\end{array}$ \\
\hline $\begin{array}{l}\text { Katz and colleagues, } \\
2013 \text { [15] }\end{array}$ & $\begin{array}{l}\text { Symptomatic meniscal } \\
\text { tear; age } \geq 45 \text { years; } \\
6 \text {-month and } 12 \text {-month } \\
\text { follow-up }\end{array}$ & $\begin{array}{l}\text { APM and } \\
\text { postoperative } \\
\text { PT, } n=161 ; \\
\text { mean age } \\
59.9 \pm 7.9 \text { years }\end{array}$ & $\begin{array}{l}\text { PT alone, } n=169 ; \\
\text { mean age } \\
57.8 \pm 6.8 \text { years }\end{array}$ & N/A & N/A & Symptoms & $\begin{array}{l}\text { WOMAC at } 6 \text { and } 12 \text { months: } \\
\text { improvement in both groups } \\
\text { but no between-group differences; } \\
30 \% \text { crossover from PT alone } \\
\text { within first } 6 \text { months }\end{array}$ & $\begin{array}{l}\text { PT non-inferior to } \\
\text { APM + PT for pain } \\
\text { reduction }\end{array}$ \\
\hline $\begin{array}{l}\text { Herrlin and colleagues, } \\
2013 \text { [17] }\end{array}$ & $\begin{array}{l}\text { Symptomatic medial } \\
\text { meniscal tear and } \\
\text { radiographic OA; } \\
\text { 24-month and } \\
\text { 60-month follow-up }\end{array}$ & $\begin{array}{l}\text { APM followed by } \\
\text { exercise therapy } \\
\text { for } 2 \text { months, } \\
n=47 ; \text { median } \\
\text { age } 54 \text { years }\end{array}$ & $\begin{array}{l}\text { Exercise therapy } \\
\text { alone, } n=49 ; \\
\text { median age } \\
56 \text { years }\end{array}$ & N/A & N/A & Symptoms & $\begin{array}{l}\text { Clinical improvement from } \\
\text { baseline to the follow-up in } \\
\text { both groups on all subscales of } \\
\text { KOOS, LKS and VAS }(P<0.0001) \text {. } \\
\text { One third of exercise-alone } \\
\text { patients that failed to respond } \\
\text { had a benefit from then } \\
\text { having APM }\end{array}$ & $\begin{array}{l}\text { Exercise alone } \\
\text { non-inferior to } \\
\text { APM + exercise }\end{array}$ \\
\hline $\begin{array}{l}\text { Herrlin and colleagues, } \\
2007 \text { [14] }\end{array}$ & $\begin{array}{l}\text { Knee pain and } \\
\text { underlying OA with } \\
\text { medial meniscal tear; } \\
\text { mean age } 56 \text { years; } \\
\text { 8-week and 6-month } \\
\text { follow-up }\end{array}$ & $\begin{array}{l}\text { APM and } \\
\text { supervised } \\
\text { exercise, } n=47\end{array}$ & $\begin{array}{l}\text { Supervised } \\
\text { exercise alone, } \\
n=43\end{array}$ & N/A & N/A & Symptoms & $\begin{array}{l}\text { Both groups reported decreased } \\
\text { knee pain, improved function and } \\
\text { high satisfaction. No between-group } \\
\text { differences }\end{array}$ & $\begin{array}{l}\text { Exercise alone } \\
\text { non-inferior to } \\
\text { APM + exercise }\end{array}$ \\
\hline Beidert, 2000 [10] & $\begin{array}{l}\text { Painful intrasubstance } \\
\text { medial meniscal tear; } \\
\text { mean age } 30.4 \text { years } \\
\text { (range } 16 \text { to } 50 \text { years); } \\
\text { 26.5-month follow-up }\end{array}$ & APM, $n=11$ & $\begin{array}{l}\text { Suture repair, } \\
n=10\end{array}$ & $\begin{array}{l}\text { Minimal } \\
\text { resection, } \\
\text { fibrin clot, } \\
\text { suture repair, } \\
n=7\end{array}$ & $\begin{array}{l}\text { PT and } \\
\text { NSAIDs, } n=12\end{array}$ & Symptoms & $\begin{array}{l}\text { Normal/near-normal IKDC. Group 4, } \\
\text { 75\%; Group 2,90\%; Group 3, 43\%; } \\
\text { Group 1, } 100 \%\end{array}$ & $\begin{array}{l}\text { APM superior to } \\
\text { conservative therapy }\end{array}$ \\
\hline
\end{tabular}


Table 3 Evidence for conservative therapy (Continued)

\section{Weight loss}

Teichtahl and No previous diagnosis of Medial meniscal knee $\mathrm{OA}$; recruited from tear on $\mathrm{MRI}$, No medial weight-loss clinics: mean $n=36$ : mean age

age 45.7 years; 2.4 -year $\quad 51.0 \pm 7.5$ years

meniscal tear

N/A

on MRI, $n=161$

follow-up

$45.8 \pm 8.9$ years

N/A

A

\section{Structure.}

people with medial meniscal

tears: every $1 \%$ change in weight

associated with change in media

tibial cartilage volume (95\% C

0.1 to $0.3 \%, P<0.001)$ and change

in WOMAC knee pain $(95 \% \mathrm{Cl} 2.1$

to $21.1, P=0.02$ )
Weight loss associated with reduced cartilage loss and improved pain only in people with

medial meniscal tears. Weight gain increased cartilage loss and knee pain

APM, arthroscopic partial menisectomy; Cl, confidence interval; MRI, magnetic resonance imaging; N/A, not available; NSAID, nonsteroidal anti-inflammatory drug; OA, osteoarthritis; PT, phsycal therapy. Western Ontario APM, a ritis Out ritis Outcom Scor (KOOS) evaluates short-term and long-term patient-related outcomes following injury including pain, other symptoms such as catching/locking/swelling, activities of daily living, sport and recreation function, and knee-related quality of life. Lysholm knee scoring (LKS) scale for knee ligament injuries including pain, swelling, locking, limping, stair climbing, support and squatting. Visual analogue scale (VAS) is a subjective measurement of pain consisting of a line $10 \mathrm{~cm}$ long where on one end is "no pain" and on the other is the "worst pain imaginable. International Knee Documentation Committee score (IKDC) is a ate knee ligament injuries including three domains of symptoms (pain, locking, catching, swelling, stiffness), sports and daily activities and current knee function (compared with old knee function). 
APM may therefore only be indicated in people who do not respond to conservative therapies. Whether or not this can be generalised to people who have mechanical symptoms, such as knee locking, is unclear since studies have not specified which knee symptoms were present. Stratifying outcomes according to the indication of the surgery being either knee pain or mechanical symptoms may help to better understand which individuals may benefit from a surgical approach. Perhaps surgery is beneficial when mechanical symptoms predominate. Likewise, the location and type of meniscal tear may be an important and underappreciated determinant of treatment response, and future efforts should focus on examining this possibility.

Finally, studies have predominantly defined outcome on the basis of symptoms. There is no clear evidence as to whether the risk of developing knee OA, or showing increased progression of knee OA, is affected by surgical intervention comprising either APM or meniscal repair. Determining whether these procedures influence structural progression (for example, alter the rate of cartilage loss, metaphyseal bone expansion, incident or progressing bone marrow lesions, and so forth) will be important in helping to understand whether such procedures impart deleterious structural changes.

\section{Conclusions}

Surgical approaches to the treatment of meniscal pathology can be broadly categorised as menisectomy or repair. Clearly the major distinguishing factor determining the choice of operative approach is age, whereby meniscal repair is performed exclusively on younger populations while older populations undergo menisectomy procedures. Nevertheless, middle-aged to older adults with meniscal tears often have coexisting degenerative changes in other knee joint structures. In such populations, APM may be treating the meniscus tear in isolation and not addressing the degenerative whole-organ disease of knee OA. Thus far, there is no convincing evidence that demonstrates the superiority of operative approaches to conservative measures for the treatment of people aged approximately 45 years or older with knee pain and meniscal tears. The available data would support a trial of conservative therapy as first-line treatment of meniscal tears in older adults, before consideration of APM. Studies have not, however, stratified populations according to mechanical symptoms, such as knee locking, and it may be that operative interventions are required to derive functional benefits in such subgroups. In younger individuals, meniscal repair is possible, although there is a paucity of data to explore whether this provides greater symptom benefit than conservative measures.

\section{Abbreviations}

ACL: Anterior cruciate ligament; APM: Arthroscopic partial menisectomy; IKDC: International Knee Documentation Committee; OA: Osteoarthritis; RCT: Randomised controlled trial.

\section{Competing interests}

The authors declare that they have no competing interests.

\section{Published: 20 Mar 2014}

\section{References}

1. Englund M, Guermazi A, Gale D, Hunter DJ, Aliabadi P, Clancy M, Felson DT: Incidental meniscal findings on knee MRI in middle-aged and elderly persons. N Engl J Med 2008, 359:1108-1115.

2. Berthiaume MJ, Raynauld JP, Martel-Pelletier J, Labonté F, Beaudoin G, Bloch DA, Choquette D, Haraoui B, Altman RD, Hochberg M, Meyer JM, Cline GA, Pelletier JP: Meniscal tear and extrusion are strongly associated with progression of symptomatic knee osteoarthritis as assessed by quantitative magnetic resonance imaging. Ann Rheum Dis 2005, 64:556-563.

3. Jackson BD, Teichtahl AJ, Morris ME, Wluka AE, Davis SR, Cicuttini FM: The effect of the knee adduction moment on tibial cartilage volume and bone size in healthy women. Rheumatology (Oxford) 2004, 43:311-314.

4. Fairbank TJ: Knee joint changes after meniscectomy. J Bone Joint Surg Br 1948, 30B:664-670

5. Roos H, Lauren M, Adalberth T, Roos EM, Jonsson K, Lohmander LS: Knee osteoarthritis after meniscectomy: prevalence of radiographic changes after twenty-one years, compared with matched controls. Arthritis Rheum 1998, 41:687-693.

6. Pengas IP, Assiotis A, Nash W, Hatcher J, Banks J, McNicholas MJ: Total meniscectomy in adolescents: a 40-year follow-up. J Bone Joint Surg B 2012, 94:1649-1654.

7. Ihn JC, Kim SJ, Park IH: In vitro study of contact area and pressure distribution in the human knee after partial and total meniscectomy. Int Orthop 1993, 17:214-218.

8. Hede A, Larsen E, Sandberg H: The long term outcome of open total and partial meniscectomy related to the quantity and site of the meniscus removed. Int Orthop 1992, 16:122-125.

9. Kim S, Bosque J, Meehan JP, Jamali A, Marder R: Increase in outpatient knee arthroscopy in the United States: a comparison of National Surveys of Ambulatory Surgery, 1996 and 2006. J Bone Joint Surg Am 2011, 93:994-1000.

10. Biedert RM: Treatment of intrasubstance meniscal lesions: a randomized prospective study of four different methods. Knee Surg Sports Traumatol Arthrosc 2000, 8:104-108

11. Englund M, Lohmander LS: Risk factors for symptomatic knee osteoarthritis fifteen to twenty-two years after meniscectomy. Arthritis Rheum 2004, 50:2811-2819.

12. Englund M, Roos EM, Lohmander LS: Impact of type of meniscal tear on radiographic and symptomatic knee osteoarthritis: a sixteen-year follow-up of meniscectomy with matched controls. Arthritis Rheum 2003, 48:2178-2187

13. Pearse EO, Craig DM: Partial meniscectomy in the presence of severe osteoarthritis does not hasten the symptomatic progression of osteoarthritis. Arthroscopy 2003, 19:963-968.

14. Herrlin S, Hallander M, Wange P, Weidenhielm L, Werner S: Arthroscopic or conservative treatment of degenerative medial meniscal tears: a prospective randomised trial. Knee Surg Sports Traumatol Arthrosc 2007, 15:393-401.

15. Katz JN, Brophy RH, Chaisson CE, de Chaves L, Cole BJ, Dahm DL, Donnell-Fink LA, Guermazi A, Haas AK, Jones MH, Levy BA, Mandl LA, Martin SD, Marx RG, Miniaci A, Matava MJ, Palmisano J, Reinke EK, Richardson BE, Rome BN, Safran-Norton CE, Skoniecki DJ, Solomon DH, Smith MV, Spindler KP, Stuart MJ, Wright J, Wright RW, Losina E: Surgery versus physical therapy for a meniscal tear and osteoarthritis. N Engl J Med 2013, 368:1675-1684.

16. Yim JH, Seon JK, Song EK, Choi Jl, Kim MC, Lee KB, Seo HY: A comparative study of meniscectomy and nonoperative treatment for degenerative horizontal tears of the medial meniscus. Am J Sports Med 2013, 41:1565-1570

17. Herrlin SV, Wange PO, Lapidus G, Hallander M, Werner S, Weidenhielm L: Is arthroscopic surgery beneficial in treating non-traumatic, degenerative 
medial meniscal tears? A five year follow-up. Knee Surg Sports Traumatol Arthrosc 2013, 21:358-364.

18. Sihvonen R, Paavola M, Malmivaara A, Itala A, Joukainen A, Nurmi H, Kalske J, Järvinen TL, Finnish Degenerative Meniscal Lesion Study (FIDELITY) Group: Arthroscopic partial meniscectomy versus sham surgery for a degenerative meniscal tear. N Engl J Med 2013, 369:2515-2524

19. Garrett WE Jr, Swiontkowski MF, Weinstein JN, Callaghan J, Rosier RN, Berry DJ, Harrast J, Derosa GP: American Board of Orthopaedic Surgery Practice of the Orthopaedic Surgeon: Part-II, certification examination case mix. J Bone Joint Surg Am 2006, 88:660-667.

20. DeHaven KE: Decision-making factors in the treatment of meniscus lesions. Clin Orthop Relat Res 1990, 252:49-54.

21. Jarvela S, Sihvonen R, Sirkeoja $H$, Jarvela T: All-inside meniscal repair with bioabsorbable meniscal screws or with bioabsorbable meniscus arrows: a prospective, randomized clinical study with 2-year results. Am J Sports Med 2010, 38:2211-2217.

22. Bryant D, Dill J, Litchfield R, Amendola A, Giffin R, Fowler P, Kirkley A: Effectiveness of bioabsorbable arrows compared with inside-out suturing for vertical, reparable meniscal lesions: a randomized clinical trial. Am J Sports Med 2007, 35:889-896.

23. Hantes ME, Zachos VC, Varitimidis SE, Dailiana ZH, Karachalios T, Malizos KN: Arthroscopic meniscal repair: a comparative study between three different surgical techniques. Knee Surg Sports Traumatol Arthrosc 2006, 14:1232-1237.

24. Albrecht-Olsen P, Kristensen G, Burgaard P, Joergensen U, Toerholm C: The arrow versus horizontal suture in arthroscopic meniscus repair. $A$ prospective randomized study with arthroscopic evaluation. Knee Surg Sports Traumatol Arthrosc 1999, 7:268-273

25. Sommerlath KG: Results of meniscal repair and partial meniscectomy in stable knees. Int Orthop 1991, 15:347-350.

26. Stein T, Mehling AP, Welsch F, von Eisenhart-Rothe R, Jager A: Long-term outcome after arthroscopic meniscal repair versus arthroscopic partial meniscectomy for traumatic meniscal tears. Am J Sports Med 2010, 38:1542-1548.

27. Melton JT, Murray JR, Karim A, Pandit H, Wandless F, Thomas NP: Meniscal repair in anterior cruciate ligament reconstruction: a long-term outcome study. Knee Surg Sports Traumatol Arthrosc 2011, 19:1729-1734.

28. DeHaven KE: Decision-making factors in the treatment of meniscus lesions. Clin Orthop Relat Res 1990, 252:49-54.

29. DeHaven KE, Arnoczky SP: Meniscus repair: basic science, indications for repair, and open repair. Instr Course Lect 1994, 43:65-76.

30. Rodeo SA, Warren RF: Meniscal repair using the outside-to-inside technique. Clin Sports Med 1996, 15:469-481.

31. Schulte KR, Fu FH: Meniscal repair using the inside-to-outside technique. Clin Sports Med 1996, 15:455-467.

32. Albrecht-Olsen PM, Bak K: Arthroscopic repair of the bucket-handle meniscus. 10 failures in 27 stable knees followed for 3 years. Acta Orthop Scand 1993, 64:446-448.

33. Noyes FR, Chen RC, Barber-Westin SD, Potter HG: Greater than 10-year results of red-white longitudinal meniscal repairs in patients 20 years of age or younger. Am J Sports Med 2011, 39:1008-1017.

34. Teichtahl AJ, Wluka AE, Wang Y, Strauss BJ, Proietto J, Dixon JB, Jones G, Forbes A, Kouloyan-llic S, Martel-Pelletier J, Pelletier JP, Cicuttini FM: The longitudinal relationship between changes in body weight and changes in medial tibial cartilage, and pain among community-based adults with and without meniscal tears. Ann Rheum Dis 2013, 6:6.

$10.1186 / \operatorname{ar} 4515$

Cite this article as: Mezhov et al: Meniscal pathology - the evidence for treatment. Arthritis Research \& Therapy 2014, 16:206 